\title{
Eating disorders that impact sports performance
}

Trastornos alimentarios que repercuten en el desempeño deportivo

Segundo Víctor Medina Paredes. ${ }^{1}$, Julio Alfonso Mocha Bonilla. ${ }^{2}$, María Teresa Naranjo Reino. $^{3}$, \& Angélica Fernanda Lozada Tuarez. ${ }^{4}$

Recibido: 10-02-2019 / Revisado: 15-02-2019 /Aceptado: 04-03-2019/ Publicado: 14-06-2019

\begin{abstract}
.
https://doi.org/10.33262/cienciadigital.v3i2.5.529

There are several aspects that involve the training of athletes, within which nutrition is vital, however, it has now been identified that anorexia and bulimia nervosa are the eating disorders that have the greatest effect on people who practice sport. The objective of this study is to identify the main eating disorders that affect performance in individual and collective sports, therefore, a qualiquantitative methodology was developed to understand how eating disorders affect individual and collective sports; the study included 52 teenagers whose ages range from 14 to 18 years, two groups were established depending on the type of sport: individual sport (n:26) and sports collectively (n:26), the instrument for collecting information was a structured questionnaire. The numerical data of the direct actors through the analysis and interpretation of the data have made it possible to draw conclusions and propose alternative solutions for sportsmen and
\end{abstract}

\footnotetext{
${ }^{1}$ Universidad Técnica de Ambato, Facultad de Ciencias Humanas y de la Educación, Carrera de Cultura Física y Pedagogía de la Actividad Física y Deporte. Ambato, Ecuador. sv.medina@uta.edu.ec

${ }^{2}$ Universidad Técnica de Ambato, Facultad de Ciencias Humanas y de la Educación, Carrera de Cultura Física y Pedagogía de la Actividad Física y Deporte. Ambato, Ecuador. ja.mocha@uta.edu.ec

${ }^{3}$ Universidad Técnica de Ambato, Facultad de Ciencias Humanas y de la Educación, Carrera de Cultura Física y Pedagogía de la Actividad Física y Deporte. Ambato, Ecuador. mt.naranjo@uta.edu.ec

${ }^{4}$ Universidad Técnica de Ambato, Facultad de Ciencias Humanas y de la Educación, Carrera de Cultura Física y Pedagogía de la Actividad Física y Deporte. Ambato, Ecuador. af.lozada@uta.edu.ec
} 
women with eating disorders, while at the same time preventing future problems for those who are vulnerable to these eating disorders.

Keywords: Eating disorders, performance, sports, teenagers.

\section{Resumen.}

Existen varios aspectos que implican la formación de los deportistas, dentro de los cuales la nutrición es vital, sin embargo, en la actualidad se ha identificado que la anorexia y la bulimia nerviosa son los trastornos alimentarios que tienen mayor efecto en las personas que practican deporte. El objetivo del presente estudio es identificar los principales trastornos alimenticios que afectan el rendimiento en los deportes individuales y colectivos, por tanto, se desarrolló una metodología cualicuantitativa que permita comprender como afectan los trastornos alimentarios en los deportes individuales y colectivos; en el estudio participaron 52 adolescentes deportistas cuyas edades oscilan entre 14 a 18 años, se establecieron dos grupos en función del tipo de práctica deportiva: deporte individual (n:26) y deportes colectivamente (n:26), el instrumento de recolección de la información fue un cuestionario estructurado. Los datos numéricos de los actores directos a través del análisis e interpretación de los datos han permitido llegar a obtener conclusiones y plantear alternativas de solución para los deportistas que atraviesan problemas de trastornos alimenticios, a su vez prevenir futuros problemas a quienes se encuentren vulnerables con dichas afectaciones alimentarias.

Palabras claves: Trastornos alimentarios, desempeño, deportes, adolescentes.

\section{Introduction.}

The practice of certain sports, especially those of a feminine nature, are considered as a "profession of risk" since it demands to be very "thin", since a greater incidence in Eating Disorders is recognized (Dosil Díaz, 2012). More than 60\% of professional sportswomen experience the so-called Eating Disorders, whose obsession with losing weight and improving their figure leads to several pathologies. 
The context in which competitive sport is developed, requires meeting a series of demands that are oriented towards perfectionism of the body. The combination trainer - sportsman focused on the quantity of muscular mass has given way to training based on quality. The scientific progress linked to sport and physical activity has been achieved through sports medicine specialists, physiologists, physiotherapists, sports psychologists, anthropometrists and nutritionists to improve people's sports performance by applying personalised training plans (Martínez, 2012), prescription of exercises and recommended dietary supplementation (García, 2019).

Food is important in the world of sport, not only as a factor that covers energy and nutritional needs, but as an effective tool that leads to optimal sports performance. This means that, as in all activity and sport, good nutrition leads to good physical performance (Blasco, 2013), while a sedentary lifestyle is one of the enemies of good health and quality of life (Mocha Bonilla, 2018). There are several measures to take into account to optimize physical-sports performance, adequate physical preparation, invisible training, psychological preparation, restorative rest, balanced nutrition leaving aside the consumption of aggressive food, known as junk food (Utrera, 2018).

At present there is a growing interest in society to maintain the cult of his body, focused on the use of low-fat diets (Gonzalez, 2019), this leads to the growing success of gyms, beauty centers, dietetic foods or known as light, plastic surgeries, among others, which are clear manifestations to maintain a good body shape. This phenomenon, undoubtedly, has positive aspects because they point out the concern of the collectivity for healthy models for women (Izquierdo Miranda, 2013); This leads to the growth of the practice of physical activities and a correct intake of nutrients that help eradicate overweight and obesity, however, there is also the appearance of negative factors such as the extreme cult of the body, there are those who are obsessed, promoting a perennial dissatisfaction that constitutes the origin of serious pathologies (Grandjean, 1991), ie eating disorders (TCA) are characterized by a persistent alteration of behavior related to the fact of eating that negatively impacts on health (Candela, 2018).

Certainly there are sports considered high risk as well as athletes with eating disorders in almost all sports disciplines, especially occurs and affects the female sex (Behar, 2012), on the other hand (Galilee, 2012) denies that there is evidence of the relationship sport - eating behavior disorder, however, specialists in eating disorders believe that in recent times there is a progressive increase in the number of cases, some even call it a "silent epidemic; There is talk of "carrier girls" (Morandé, 2015), women between the ages of 15 and 25 with a medium socioeconomic level, a population at high risk of acquiring anorexia (Grandjean, 1991), teenagers who are obsessed with aesthetics and food, and that these in turn can cause other people in their environment to become ill. 
Since the sixties, with an emphasis on the seventies, studies on anorexia have been disseminated; this points to a marked interest on the part of scholars such as (Hilde, 2003) and (Turón, 2012) who point out the relevance of eating disorders and the drawbacks in metabolism, while Russell, (2010) tried to simplify the so-called biological trends that emphasized the role played by the hypothalamus in the origin of the disease, combining the psychological and sociological; researchers such as Garfinkel and Garner take anorexia nervosa as a disease of complex pathology, with clinical manifestations resulting from several triggers (Tobal, 2002), according to current diagnostic criteria, anorexia nervosa is a modern disease, whose central aspect is in the fear of gaining weight (Rutsztein, 2017) in addition its manifestations affect the image of the body and harmonious development (Gonzalez, 2018).

Undoubtedly, the eating disorders to which athletes are more prone are anorexia and bulimia nervosa, where there is a significant growth of attitudes and behaviors associated with such alterations, appears an overvaluation towards excessive concern for body volume, as well as attitudes aimed at reducing body weight through exercise, accompanied by so-called restrictive diets which are associated with diseases of eating behavior (Toro, 2016); According to the researchers Resch, (2013), Sánchez Molina, Ibáñez Salmerón and García, Pérez-Carro (2011) there is a variation in prevalence from $62 \%$ with affectation in more than $90 \%$ in teenagers preferably women, while Costill and Wilmore (2012) consider a 50\% prevalence for elite sportswomen (Williams, 2002).

The society in which thinness is valued, it is complicated to carry out an objective examination of nutritional habits and calorie intake (Lozano, 2019), certain sportsmen try to control their weight through intense exercise, leading to nutritional problems in women who participate in athletics and dance (Garfinkel, 2011) as well as in gymnastics, trampoline, figure skating, because in these activities the body image becomes part of a subjective judgment (Teitz, 2013), Similar cases occur in long-distance runners and volleyball players Squire, (2011) and Finch, (2012), with which there is evidence of female athletes who have nutrition problems in sports disciplines (Toro, 2012), so that despite the dizzying weight loss in athletes, almost never accept having been on a diet, in any case, eating disorders reduce performance, because they overvalue physical appearance and thinness as a stereotyped aesthetic value (Rosas, 2010).

Studies carried out on eating behavior try to conceive it from an integral perspective, taking into account biological, psychological and cultural characteristics; a behavioural change in their habits towards weight loss, making them aware of dietary restriction and promoting physical activity; since weight gain leads to an increase in the risk of contracting cardiovascular diseases (González, 2019), from coronary diseases to those known as metabolic diseases. According to the Diagnostic and Statistical Manual of Mental Disorders, FIFTH EDITION (DSM-5) of the American Psychological Association (2017), eating disorders are related to anorexia and bulimia nervosa; anorexia nervosa (AN) describes the 
eating disorder, with impulsive and compulsive facets that contribute to variations in compulsive purging, restrictive eating and maladaptive cognitions (Brooks, 2019), bulimia nervosa $(\mathrm{BN})$ is characterized by deregulated food intake, which can cause a homeostatic imbalance (Grethe, 2019) while sports or athletic anorexia is defined as a state that has prevalence among sportswomen and is characterized by the appearance of an intense fear of improving their weight, even if thin.

One of the main reasons why it was decided to conduct this study was to find high data and rates of young people with Anorexia Nervosa 1 per 100,000 people per year, while Bulimia Nervosa presents 11.4 per 100,000 people per year, high-risk groups whose combined prevalence rate for Anorexia Nervosa, Bulimia Nervosa and obesity is present in adolescents (Plaza, 2014). From this, it is estimated a prevalence in adolescents who present symptoms of eating disorders and the exaggerated interest in body weight (Rodríguez Martín, 2011), based on the supporting literature the objective of the study is to identify the main eating disorders that affect performance in individual and collective sports according to gender.

\section{Methodology.}

A descriptive cross-sectional study of observational type was carried out; it was crosssectional because the variable was studied in a single moment and in a determined time, descriptive because it allowed to describe the eating disorders within a selected sample, and observational because the study does not require a later follow-up, because it is of analytical type since the data of the variable was collected and simultaneously obtained results of interest in the defined sample.

Participants: We worked with 52 adolescents who play sports, whose ages are between 14 and 18 years, which were selected by random sampling, then we established two groups depending on the type of sport: individual sport (26 athletes) and for sports collectively (26 athletes). Eating habits in both groups were analysed using a structured questionnaire.

Instrument: In order to collect data, a field work was carried out, whose supporting evidence and information were directly collected at the scene of the events, training in the different sports disciplines. The instrument used to obtain the data was the questionnaire aimed at obtaining information on eating disorders, which included nine questions.

Protocol: We went to the sports facilities in the province of Tungurahua where adolescents practice the sports of their preference, both individual and collective, establishments where a random sampling was carried out taking into account the sports with the greatest number of people, in the same way we selected the best known and practiced sports in the sociosports environment, whose working hypothesis aims to determine the presence of eating disorders in adolescent sportsmen according to gender and the type of sport they practice. 


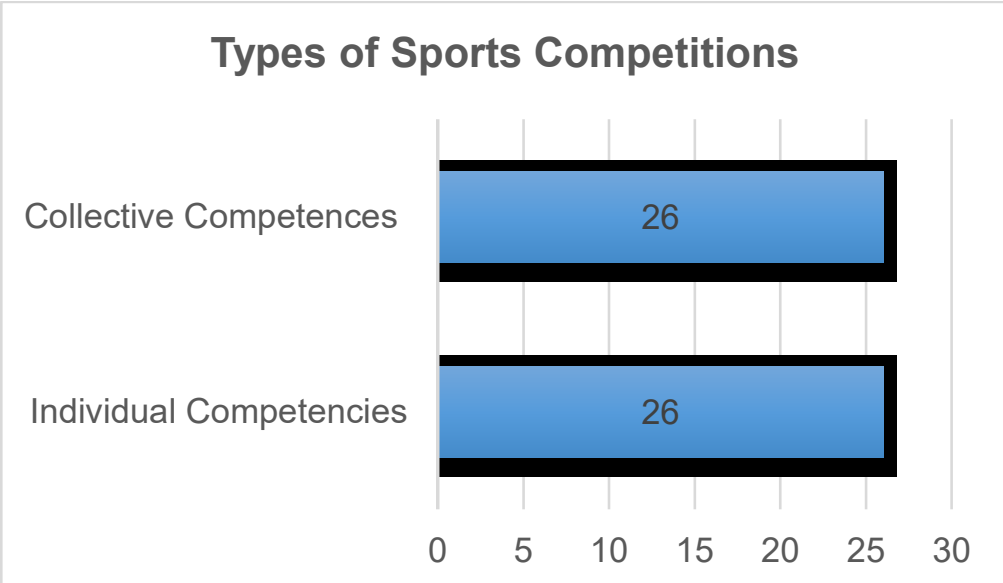

Figure 1. Classification of athletes

Source: Prepared by the authors.

In Figure 1. Two groups are observed depending on the type of sports practice; for individual sports 26 participants and for collective sports 26 participants. Thus, the groups have not been biased in order to know in which group eating disorders predominate.

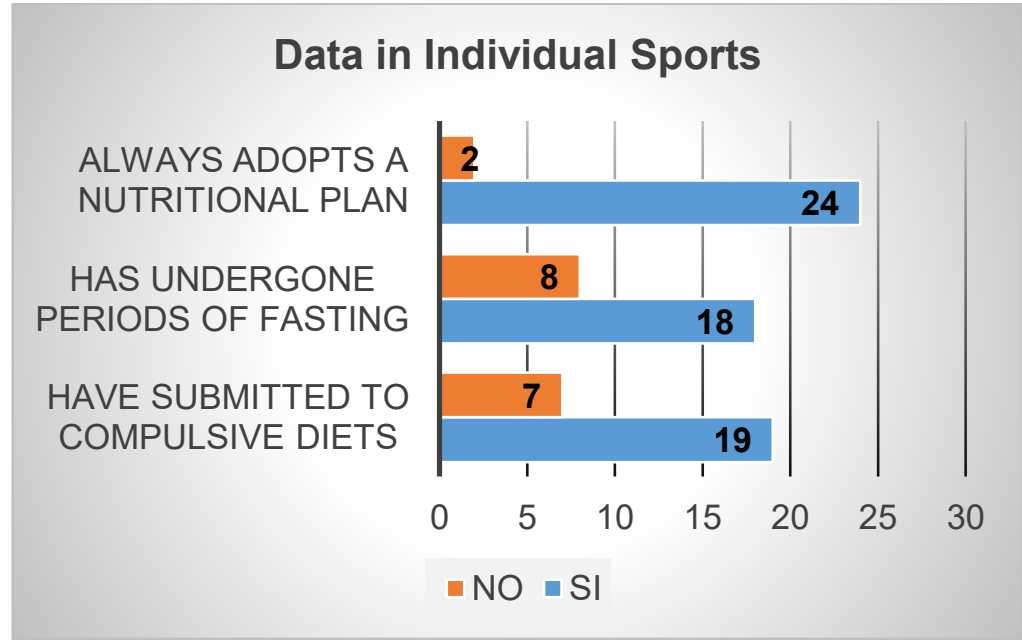

Figure 2. Data Collection in Individual Sports.

Source: Prepared by the authors.

In the figure 2 corresponding to the individual sports, in the group of individual athletes it is observed that 2 participants do not adopt a nutritional plan, while 24 participants do adopt a nutritional plan; on the other hand 8 participants have not undergone periods of fasting, while 18 participants have undergone periods of fasting; in turn, 7 participants have not undergone compulsive diets, so 19 participants have undergone compulsive diets. 


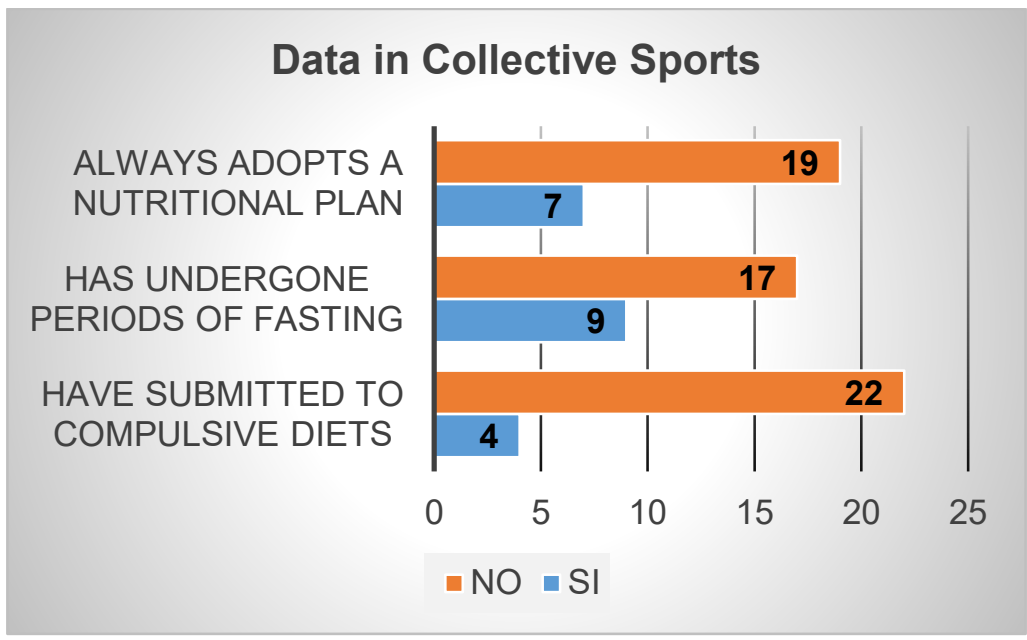

Figure 3. Data collection in Collective Sports.

Source: Prepared by the authors.

In the figure 3 corresponding to group sports, in the group of sportsmen as a whole it is observed that 7 participants if they adopt a nutritional plan, while 19 participants do not adopt a nutritional plan; on the other hand 17 participants have not undergone periods of fasting, while 9 participants have undergone periods of fasting; in turn, 22 participants have not undergone compulsive diets, so 4 participants if they have undergone compulsive diets.

\section{Survey of the women's group}

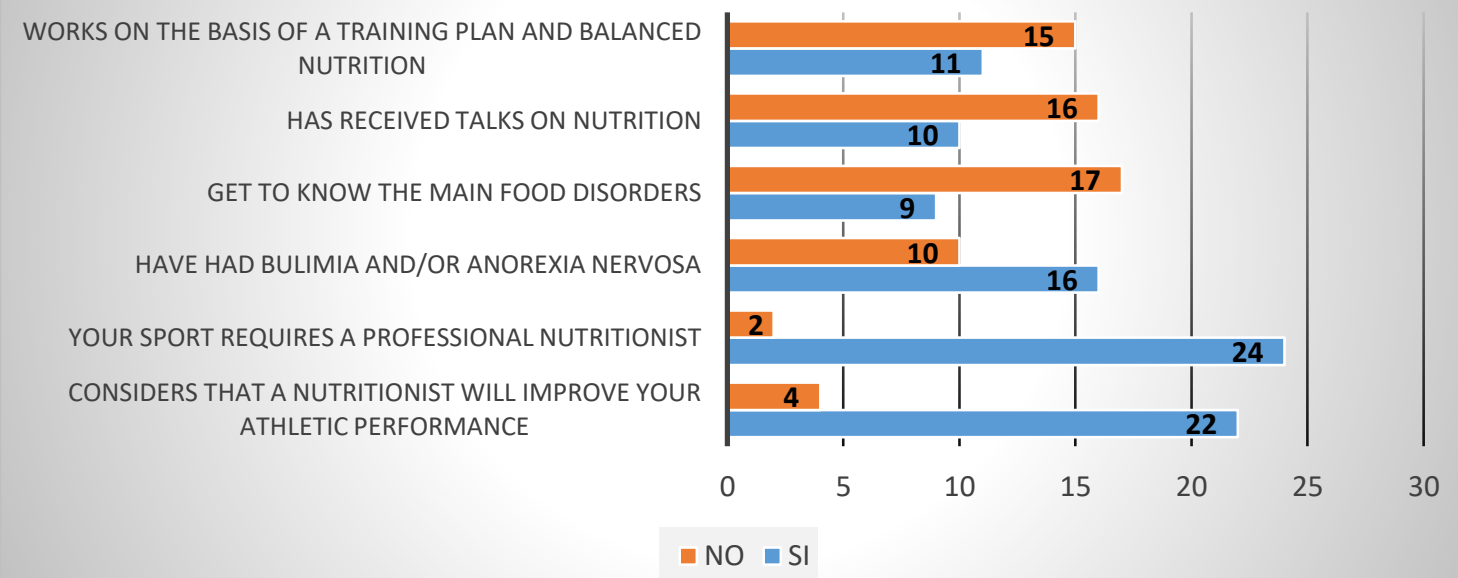

Figure 4. Survey applied to the group of women. Source: Prepared by the authors.

Figure 4. It shows the data from the survey applied to the group of women it is observed that 15 women do not train on the basis of a nutrition plan, while 11 women do train on the basis 
of a nutrition plan; while 16 women mention not having received nutrition talks and 10 claim to have received nutrition talks; in turn 17 women do not know the main eating disorders and 9 women claim to know about these disorders; while 10 women mention that they do not suffer from bulimia or anorexia nervosa and 16 affirm that they suffer from eating disorders; in relation to the requirement of a professional nutritionist 2 women are mentioned negatively, while 24 women affirm that a professional nutritionist is indispensable in sport; finally 4 women consider that the nutritionist does not help to improve sports performance, while 22 women consider that the nutritionist will improve sports performance.

\section{Men's Group Survey}

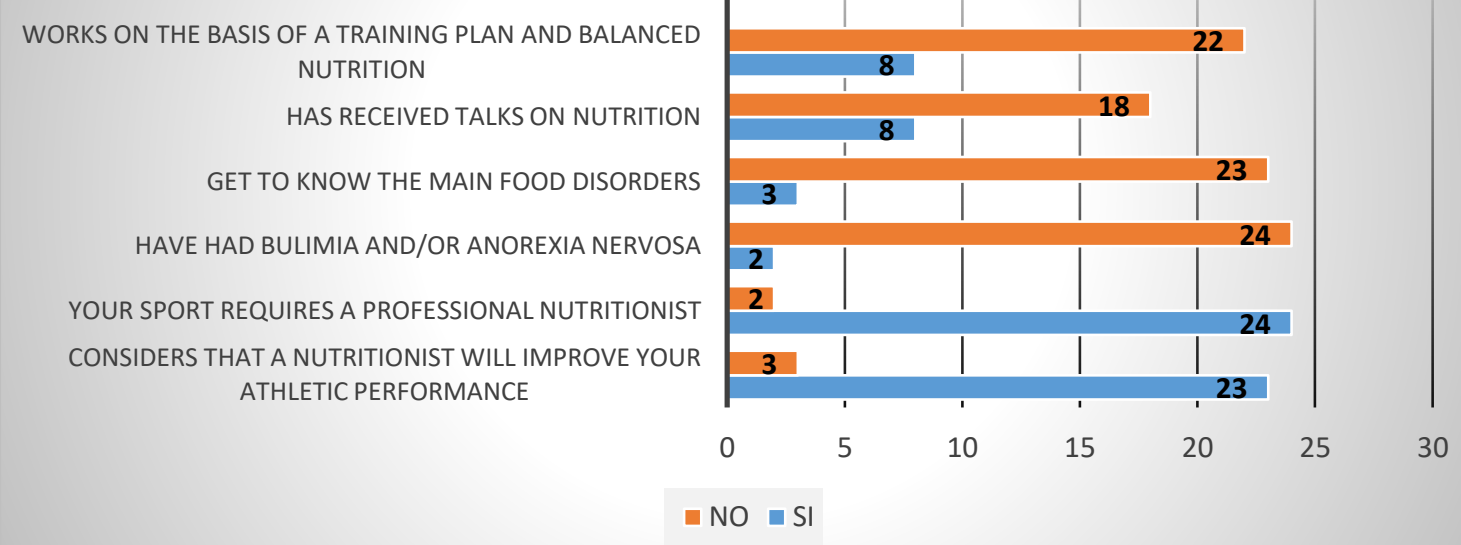

Figure 5. Survey applied to the group of men.

Source: Prepared by the authors.

Figure 5 shows the data from the survey applied to the group of men where 22 men mention they do not train based on a nutrition plan, while 8 men say they train based on a nutrition plan; 18 men mention they have not received nutrition talks and 8 say they have received nutrition talks; 23 men in turn do not know the main eating disorders and 3 men say they know about the disorders; while 24 men mention that they do not suffer from bulimia or anorexia nervosa and 2 say that they suffer from eating disorders; in relation to the requirement of a professional nutritionist, 2 men are mentioned negatively, while 24 men state that it is indispensable to have a professional nutritionist in sport; finally, 3 men consider 
that the nutritionist does not help to improve sports performance, while 23 men consider that the nutritionist will improve sports performance.

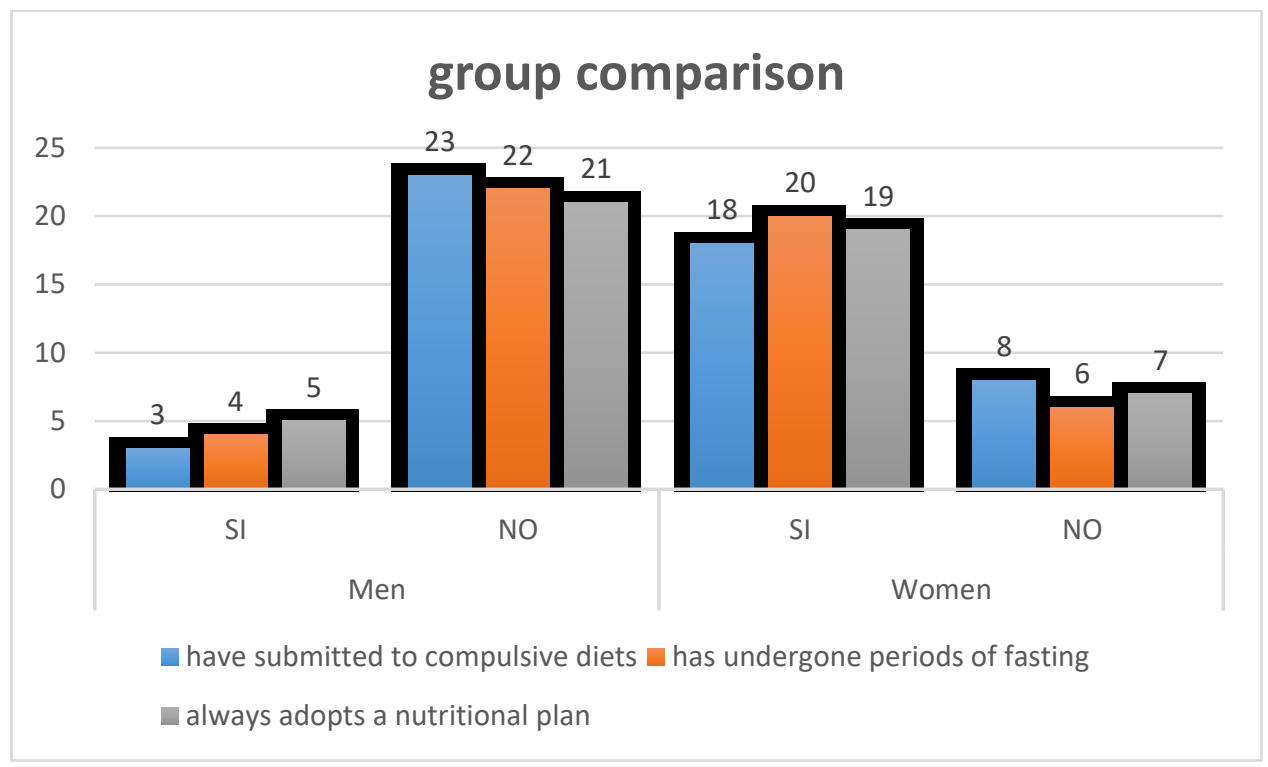

Figure 6 COMPARATION BETWEEN GROUPS

Source: Prepared by the authors.

Figure 6. Shows a comparison between study groups for analyzing eating disorders in both men and women, statistical analyses are shown below.

In the first instance, normality tests were performed, which determined that the data do not present a normality.

Table 1. Normality Tests

Kolmogorov-Smirnova Shapiro-Wilk

\begin{tabular}{lcccccr} 
& Statistics & gl & Sig. & Statistics & gl & Sig. \\
\hline $\begin{array}{l}\text { have submitted to } \\
\text { compulsive diets }\end{array}$ &, 389 & 52 &, 000 &, 623 & 52 &, 000 \\
$\begin{array}{l}\text { has undergone periods of } \\
\text { fasting }\end{array}$ &, 359 & 52 &, 000 &, 635 & 52 &, 000 \\
$\begin{array}{l}\text { always adopts a nutritional } \\
\text { plan }\end{array}$ &, 359 & 52 &, 000 &, 635 & 52 &, 000
\end{tabular}

a. Correction of the meaning of Lilliefors

Source: Prepared by the authors.

Since there is no normality in the statistical data carried out by means of the kolmogorovsmirnov test, which shows a significance value of ,000 in the three cases, a test was applied 
for independent nonparametric samples with a significance level of $5 \%$ equivalent to the value $\mathrm{p}<0.05$, which are shown in tables 1 and 2 respectively.

Table 2. Range

\begin{tabular}{lllrr} 
& Gender & N & average range & Sum of ranges \\
\hline \multirow{4}{*}{ have submitted to compulsive diets } & men & 26 & 19,00 & 494,00 \\
& Tomen & 26 & 34,00 & 884,00 \\
& men & 52 & & 481,00 \\
has undergone periods of fasting & women & 26 & 18,50 & 897,00 \\
& Total & 52 & 34,50 & \\
& men & 26 & & 507,00 \\
always adopts a nutritional plan & women & 26 & 33,50 & 871,00
\end{tabular}

Source: Prepared by the authors.

Table 3. Contrast statistics ${ }^{a}$

have submitted to has undergone periods always adopts a

compulsive diets of fasting nutritional plan

\begin{tabular}{lrrr} 
& compulsive diets & of fasting & nutritional plan \\
\hline U de Mann-Whitney & 143,000 & 130,000 & 156,000 \\
W de Wilcoxon & 494,000 & 481,000 & 507,000 \\
Z & $-4,198$ & $-4,408$ & $-3,857$ \\
Sig. asintót. (bilateral) &, 000 &, 000 &, 000
\end{tabular}

a. Grouping variable: Gender.

Source: Prepared by the authors.

Decision: For the three cases analyzed the level of bilateral significance is 0.000 therefore there are significant differences for the three case studies, therefore it can be concluded that if there are significant differences between men and women, there is greater incidence in individual sports.

\section{Conclusions.}

Currently anorexia and bulimia nervosa are present with greater incidence in the female gender, which is confirmed in the research with emphasis on women athletes, because the advertising networks present a remarkable motivation towards the aesthetic, society is increasingly promoting beauty and thinness which leads to eating disorders, a problem that can have serious sequelae in the functioning of the body, therefore women athletes today are identified as a population at high risk for acquiring eating disorders due to social pressures. 
Of the results obtained it is highlighted that the sportsmen if they practice compulsive diets being more predominant in the group of women, reason why they have more influence of the excessive care of the corporal image and the aesthetics, this personal care combined with the sport leads to present eating disorders, reason why it is of sum important to manage balanced diets with a professional nutritionist.

As far as the alimentary conducts carried out by the young people are cited characteristics like: to adopt diets of slimming not foreseen nor advised, worse still controlled by professionals, this harms the state of health and the level of performance in the trainings and sport competitions, the evidences show the presence of altered alimentary conducts that are given with greater frequency in adolescent women having an incidence of compulsive diets and periods of fasting especially in the individual sports.

Finally, relatives close to sportsmen and women have a fundamental role to play in the integral formation of sportsmen and women, they must provide support in balanced nutrition; on the other hand, sports coaches must motivate in a positive way in order to raise awareness about the importance of an adequate eating behavior that entails valid nutrients for an organism under training conditions; the same sportsman and woman must be aware of eating in an adequate manner depending on the type of sport he or she performs in order to avoid disorders that damage his or her performance and limit his or her health.

\section{References.}

Behar, R. (2012). Quince años de investigación en trastornos de la conducta alimentaria. Revista chilena de neuro-psiquiatría,, 135-146.

Blasco, M. P.-M. (2013). Trastornos alimentarios en la actividad física y el deporte. Revista de psicología del deporte, 41-53.

Brooks, S. J. (2019). Impulsividad y compulsividad en la anorexia nerviosa: variación de los sistemas cognitivos en la restricción del apetito desde una perspectiva RDoC. En la anorexia y la bulimia nerviosa. IntechOpen, 35, 19.

Candela, C. G. (2018). Consenso sobre la evaluación y el tratamiento nutricional de los trastornos de la conducta alimentaria: anorexia nerviosa, bulimia nerviosa, trastorno por atracón y otros. 
Nutrición hospitalaria: Organo oficial de la Sociedad española de nutrición parenteral y enteral, 2, 489-494.

Dosil Díaz, J. D. (2012). Prevención y detección de los trastornos de alimentación en deportistas de alto rendimiento (CAR, CEARE y CTD). Cuadernos de Psicología del Deporte, 163-166.

Eras Diaz, P. F. (2016). Nutrición en jóvenes y adultos en beneficio del desarrollo de sus capacidades físicas. Madrid: KAPELUZ.

García, W. S. (2019). Efecto de intervenciones con ejercicio o suplementación sobre la masa muscular de personas mayores con sarcopenia: Un meta-análisis. Pensar en Movimiento: Revista de Ciencias del Ejercicio y la Salud, 17(1), e34449-e34449.

González, A. T. (2018). Las profundidades socio-psicológicas del deporte. Ciencia y Tecnología en la Cultura Física, 13(2).

González, M. R. (2019). Efectos de la dieta mediterránea sobre los factores de riesgo cardiovascular. Journal of Negative and No Positive Results, 25-51.

Grandjean, A. C. (1991). Desórdenes en la Alimentación: El Rol del Entrenador. G-SE/Editorial Board/Dpto. Contenido. PubliCE., 26(2), 105-112.

Grethe, M. P. (2019). Grethe, M. P. P., Bailer, U. F., \& Kaye, W. H. (2019). Altered Anticipation and Processing of Aversive Interoceptive. Experience among Women Remitted from Bulimia Nervosa., 15.

Izquierdo Miranda, Z. C. (2013). Artículo de revisión actualización, pronóstico y medidas de intervención para la tríada de la mujer deportista. PROGNOSTIC AND INTERVENTION RULING TO.

Lozano Vasquez, D. A. (2019). Relación de la ingesta calórica y hábitos alimentarios con el estado nutricional de la Organización de Estudiantes Indígenas. scielo(2).

Martínez Sanz, J. M. (2012). Aspectos psicológicos y sociológicos en la alimentación de los deportistas. Cuadernos de Psicología del Deporte, 39-48.

Mocha Bonilla Julio, D. J. (2018). OBESITY AND SEDENTARISM LEVELS ANALYSIS: A CASE STUDY UNIVERSIDAD TECNICA DE AMBATO-INGAHURCO CAMPUS. Ponte Journal International Journal of Sciences and Research, 74(5), 70-83. doi:10.21506/j.ponte.2018.5.7

Plaza, J. F. (2014). Medios de comunicación, anorexia y bulimia. La difusión mediática del 'anhelo de delgadez' : un análisis con perspectiva de género. ICONO. Revista científica de Comunicación y Tecnologías emergentes, 62-83.

Rodríguez Martín, A. M. (2011). Ejercicio físico y hábitos alimentarios: un estudio en adolescentes de Cádiz. Revista española de salud pública, 81-87. 
Rosas, C. E. (2010). Factores de riesgo e indicadores clínicos asociados a los trastornos de la conducta alimentaria. Revista de psicología(12), 13-50.

Rutsztein, G. (2017). El Aspecto Central de la anorexia Nerviosa. Secretaría e Instituto de Investigaciones, 80.

Tobal, M. (2002). Trastornos de la conducta alimentaria en el deporte: Anorexia y Bulimia nerviosas. Revista electrónica de motivación y emoción, 5, 11-15.

Utrera, R. R. (2018). La influencia de una correcta nutrición a partir de dietas que respondan a las necesidades de desarrollo en niños de 4 a 6 años de edad. INVESTIGACIONES CUALITATIVAS EN CIENCIA Y TECNOLOGÍA, 31, 277.

Williams, M. H. (2002). Nutrición para la salud la condición física y el deporte. Mexico: Editorial Paidotribo.

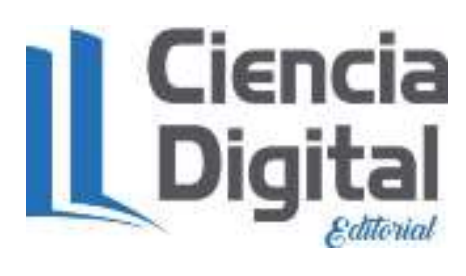

PARA CITAR EL ARTÍCULO INDEXADO.

Medina Paredes, S., Mocha Bonilla, J., Naranjo Reino, M., \& Lozada Tuarez, A. (2019). Eating disorders that impact sports performance. Ciencia Digital, 3(2.5), 46-58. https://doi.org/10.33262/cienciadigital.v3i2.5.529

\section{LC Ciencia}

El artículo que se publica es de exclusiva responsabilidad de los autores y no necesariamente reflejan el pensamiento de la Revista Ciencia Digital.

El artículo queda en propiedad de la revista y, por tanto, su publicación parcial y/o total en otro medio tiene que ser autorizado por el director de la Revista Ciencia Digital.
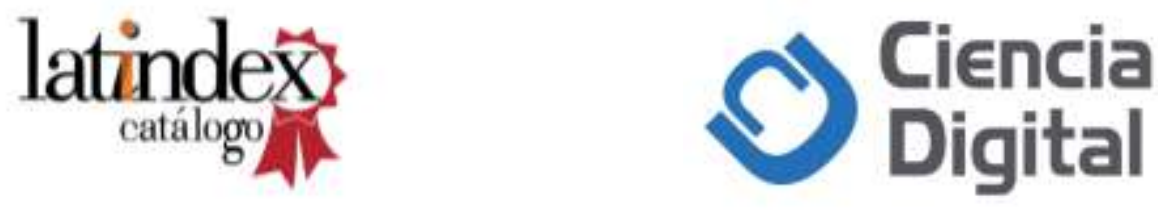